\title{
SESAMOID BONES OF THE KNEE JOINT OF THE PUMA CONCOLOR
}

\section{Č. ČERVENÝ and V. PÁRAL}

Department of Anatomy, Histology and Embryology, Faculty of Veterinary Medicine, University of Veterinary and Pharmaceutical Sciences, 61242 Brno

Received September 22, 1994

Accepted March 30, 1995

\begin{abstract}
Č e r v e n ý Č., V. Pá r a l: Sesamoid Bones of the Knee Joint of the Puma concolor. Acta vet. Brno 1995, 64:79-82.

The sesamoid bones of the knee joint were studied in three cadavers of adult pumas (Puma concolor), i.e. one female and two males, with regard to the already known and described situation in the domestic cat, in terms of its occurrence, formation and topographical-anatomical relation to the bones of the knee joint. The cadavers were obtained from zoos as a contribution to our anatomical collections. Following $\mathrm{X}$-ray examinations, the patella, ossa sesamoidea $\mathrm{m}$. gastrocnemii and os sesamoideum $\mathrm{m}$. poplitei were studied after anatomical dissection using classical osteological methods and differential staining of the bone tissue with alizarin. The heart-shaped patella of the puma is relatively wider, shorter and more flattened than that of the cat. Its os sesamoideum $\mathrm{m}$. gastrocnemii laterale is larger than the medial, as is the cat's. The shape of the os sesamoideum $\mathrm{m}$. poplitei resembles a smaller patella and is embedded in the tendomuscular transition of the respective muscle.

Oval shadows were observed in the cranial part of the femorotibial articular slit on radiographs in lateromedial projections. Based on this finding and applying the described methods and techniques, in all the examined cases we proved an osseous formation - os menisci medialis - a heterotopic bone showing lamellar osteons after routine histological examinations with HE staining. Our findings can be employed in comparative anatomy and in clinical practice, particularly when assessing radiographs of the knee region of the Puma concolor.
\end{abstract}

Puma concolor, knee joint, ossa sesamoidea

The knee joint is a very important junction of the stylopodium and zeugopodium in mammals. Strong and long muscles pass over this joint, and many supportive sesamoid bones have developed. In mammals it is regularly the patella, and in some also the ossa sesamoidea $\mathrm{m}$. gastrocnemii and os sesamoideum $\mathrm{m}$. poplitei.

$\mathrm{H} \mathrm{a} \mathrm{b} \mathrm{e} \mathrm{r} \mathrm{m} \mathrm{e} \mathrm{h} \mathrm{l} \mathrm{(1960)} \mathrm{and} \mathrm{P} \mathrm{r} \mathrm{e} \mathrm{u} \mathrm{s} \mathrm{s} \mathrm{(1970)} \mathrm{suggested} \mathrm{that} \mathrm{these} \mathrm{sesamoid} \mathrm{bones}$ around the joints or cartilaginous formations, such as corpora sesamoidea, have developed due to the increased pressure of tendons on the surface of the articular capsule during muscular activity. $\mathrm{R} \mathrm{o} \mathrm{m} \mathrm{m}$ e $\mathrm{r}$ and $\mathrm{P}$ a r s o $\mathrm{n} \mathrm{s}$ (1983) range these osseous formations among heterotopic bones. E $1 \mathrm{l} \mathrm{e} \mathrm{n} \mathrm{b}$ e r g e r and B a u m (1891), P e a r s o $\mathrm{n}$ and D a vi n (1921), B a u m and Zi e t s c h m a n n (1936), K o l d a (1942), B a r o $\mathrm{ne}$ (1960), $\mathrm{N}$ i c k e l- S c h u m m e r - S e i f e r l e (1977) and others all reported that these bones occur regularly in domestic carnivores as given above. In the domestic cat they were described by R e i g h a r d t and J e n n in g s (1930), P r o s e é (1984), Mc C a r t h y - W o od (1987) and $\mathrm{K}$ ö $\mathrm{n}$ i g (1992). No literature data were found about sesamoid bones in the region of the knee joint in other felids. R e t t e r e r (1918) studied the dorsal sesamoid bones of the digits in the lion and cat, and $\mathrm{M}$ o $\mathrm{r}$ i t $\mathrm{z}$ (1960) the suprapatellar and parapatellar cartilages of the knee joint in the cat. P f i t z n e r (1892), S t i e d a (1902) and $\mathrm{K}$ o l d a (1936) described the irregular occurrence of sesamoid bones in addition to the patella in the human knee.

On radiographs of the knee joint of the Puma concolor we found, besides the heterotopic parts of the skeleton bound to the articular capsule, a small oval shadow in the clearing of the femorotibial slit of the joint. Similar formations were described in the menisci of the knee 
joint in mammals, i.e. by $\mathrm{N} \mathrm{a} \mathrm{g} \mathrm{l}$ i e r i (1932) in the nutria and by $\mathrm{P}$ e de r s e $\mathrm{n}$ (1949) in the mouse and rat.

Since information on this problem is scarce, we decided to complete the hitherto known data on sesamoid bones of the knee joint in domestic carnivores with data on the puma (Puma concolor) and to study and describe the X-ray findings in their femorotibial slit.

\section{Materials and Methods}

We studied the knee joints of cadavers of three adult pumas (Puma concolor) aged 12 - 17 years ( 2 males and one female). Radiographs of the knee joints were taken in the lateromedial projection and were then dissected to assess the localization of the sesamoid bones and their topographical relation to the other knee structures. We then used the classical osteological method of biological maceration followed by defatting and bleaching. Finally, the bones were examined anatomically. The joint menisci were processed using the clearing technique by $\mathrm{H}$ o o d and $\mathrm{N}$ e i 1 (1948). The current histological method with hematoxylin and eosin (HE) staining was used to identify the RTG-contrast tissue in the menisci.

\section{Results}

All sesamoid bones of the knee joint of the puma (Puma concolor) are situated in topographic relations in approximately the same way as in the cat.

The shape of the patella is a craniocaudal flattened pyramid with a wider proximal base and distal rounded apex. The facies cranialis is heart-shaped, markedly convex at the base. The facies articularis is saddle-shaped, oval and does not reach the apex. The patella is situated on the trochlea of the femur in such a way that its long axis is virtually vertical. On the radiographs the shadow of the apex and the caudal part of the base of the patella are the least evident. Intensive opacity was observed on the facies articularis and on the tuberosities of the facies cranialis. The average length, width and depth of the bone is $29 \mathrm{~mm}, 22 \mathrm{~mm}$ and $14 \mathrm{~mm}$, respectively.

The os sesamoideum musculi gastrocnemii laterale - fabella lateralis - is larger than the medial, it is shaped like a sealing-stick with a round base and proximally directed handle forked at the end. The joint facies is attached to the proximal facies of the lateral condyle of the femur in such a way that the direction of the long axis of this bone is dorsocaudal, virtually parallel with the long axis of the femur. The most marked radiographic shadow can be seen near the facies articularis and in the dorsocranial part of the projection - the handle. The average length, width and depth of the bone is $19 \mathrm{~mm}, 10 \mathrm{~mm}$ and $12 \mathrm{~mm}$, respectively.

The shape of the os sesamoideum m. gastrocnemii mediale - fabella medialis - is a craniocaudally elongated ellipsoid, about half the size of the lateral fabella. The joint facies adheres to the proximal facies of the medial femur condyle in such a way that its long axis is directed craniodorsally, that is normal to the long axis of the femur. In the radiographs its shadow is partly covered by the shadow of the lateral fabella. A deeper opacity forms the outline of the bone picture. The average length, width and depth is $10 \mathrm{~mm}, 10 \mathrm{~mm}$ and 16 $\mathrm{mm}$, respectively.

The shape and arrangement of the os sesamoideum $\mathrm{m}$. poplitei - cyamella - resembles the patella, only it is smaller. The ossicle is placed in the tendon of $\mathrm{m}$. popliteus in the place where it passes into the muscle belly. The joint facies abuts to the caudolateral section of the lateral condyle of the tibia in such a way that its sharper apex is directed distally and the long axis runs in the direction of the axis of the tibia and fibula. When the knee bends, the wider base of the ossicle leans against the caudolateral margin of the meniscus. In the radiograph its picture is immediately above the margin of the joint facies of the lateral condyle of the tibia. The average length, width and depth of the ossicle is $13 \mathrm{~mm}, 12 \mathrm{~mm}$ and $7 \mathrm{~mm}$, respectively.

The os menisci medialis - lunula - is a minute ovoid bony formation in the cranial part of 
the medial meniscus and is completely submerged in its fibrocartilage. On the cleared preparations of the menisci the bone is distinctly demarcated, subtly stained with alizarin. On the radiographs it can be seen as an oval shadow in the cranial section of the slit between the joint facies of the femur and tibia. Histological sections give evidence of the microscopical structure of the spongy bone, in the trabeculae of which sporadic osteons were found.

\section{Discussion}

The puma has the same numbers of sesamoid bones as the domestic cat ( $\mathrm{R} \mathrm{e} \mathrm{i} \mathrm{g} \mathrm{h}$ a $\mathrm{rd}$ and J e n n i n g s 1930; K o 1 d a 1936; E 1 l e n b e r g e r and B a u m 1943; K o l d a 1950; B a r o n e 1968; N i c ke 11977 and K ö n i g 1992). Compared with that of the cat, the patella of the puma is more flattened and it is wider and shorter.

The authors of the present study found two ossa sesamoidea m. gastrocnemii in the Puma concolor, the lateral one being larger, as did Ell e $\mathrm{n}$ b e $\mathrm{rg}$ e $\mathrm{r}$ and $\mathrm{B}$ a u $\mathrm{m}$ (1891), B a u $\mathrm{m}$ and $\mathrm{Zi}$ e t s c h m a n n (1936) in the dog and Ko l d a (1936) in the dog and cat This difference in size may be associated with a more frequent, even though very irregular, finding of the lateral sesamoid bone of the gastrocnemius muscle in humans, as was reported by P f i t z n e r (1892), S t i e d a (1902) and K o l d a (1936). The shape of the os sesamoideum $\mathrm{m}$. poplitei of the puma is not an irregular oval, as McC a r t h y and W o o d (1978) described in the cat, but it is more like the patella that can be clearly observed on osteological preparations and in radiographs. During extension of the knee joint this ossicle touches only the tibia, but not the lateral meniscus, as P r o s é e (1984) reported in the cat. It touches this meniscus only during flexion of the knee, in accordance with the observations of Mc C a r t h y and W o o d (1987) in the cat.

The shadow in the femorotibial slit depicted in the radiograph was identified as a bone in the medial meniscus - os menisci medialis. In all mammals the patella is in the knee joint, the fabella and cyamella were observed only in some species. We consider this finding and description in the Puma concolor to be very important both in terms of comparative anatomy and clinical practice, particularly for X-ray examinations of the knee.

The bone tissue found in the medial meniscus of the adult puma was localized in the same place in all three specimens under study as shown by all methods employed.

\section{Sesamské kosti kolenního kloubu pumy americké (Puma concolor)}

U tř́ kadaverů dospělých pum amerických - Puma concolor (jedna samice a dva samci), které jsme získali ze zoologických zahrad pro obohacení našch anatomických sbírek, jsme studovali sesamské kosti v krajině kolenního kloubu vzhledem ke známé a popsané situaci u kočky domácí, a to jak jejich zastoupení, tak jejich utváření a topograficko-anatomický vztah k zúčastněným kostem kolenního kloubu. Patellu, ossa sesamoidea m. gastrocnemii i os sesamoideum m. poplitei jsme po předchozím RTG vyšetření studovali pomocí anatomické pitvy, klasických osteologických metod a diferenčního barvení kostní tkáně alizarinem. Srdčitá patella je relativně širši, kratší a více oploštělá než u kočky. Os sesamoideum $\mathrm{m}$. gastrocnemii laterale je podobně jako u kočky větší než mediální. Os sesamoideum m. poplitei se tvarem podobá zmenšené patelle a je uložena $v$ tendomuskulárním přechodu př́slušného svalu.

Na základě nálezu oválného stínu v kraniální caásti femorotibiální kloubní sttěrbiny na rentgenogramech $\mathrm{v}$ lateromediální projekci jsme popsanými metodami a technikami ve všech sledovaných prípadech prokázali v kraniální části mediálního menisku kostěný útvar - os menisci medialis - heterotopickou kost, u níz jsme běžným histologickým vyšetřením s HE barvením potvrdili Haverské lamelární systémy. Naše nálezy jsou využitelné ve srovnáva- 
cí anatomii i v klinické praxi zejména při posuzování RTG snímků kolenní krajiny pumy americké.

\section{References}

BARONE R. 1966: Anatomie comparée des mammiféres domestiques. Tome premier, Osteologie. Laboratoire d' Anatomie Ecole Nationale Veterinaire, Lyon 811 p.

BAUM H., ZIETSCHMANN O. 1936: Handbuch der Anatomie des Hundes. 1. Band, Skelett- und Muskelsystem. Paul Parey, Berlin, 242 p.

CERVENÝ C. 1971: Notes on methods of studying the structure and ossification of the ethmoid bone. Acta vet. Brno 40: 361-365

CERVENÝ Č. 1987: Radiograph of ossa sesamoidea phalangis proximalis in cattle in postnatal ontogenesis. Acta vet. Brno 56:231-249

DRIESCH A. 1976: A guide to the measurement of animal bones from archaeological sites. Peabody Museum Bulletin 1, Peabody Museum of Archeology and Ethnology Harvard University, 137 p.

ELLENBERGER W., BAUM H. 1891: Systematische und topografische Anatomie des Hundes. Verlag Paul Parey, Berlin, $646 \mathrm{p}$.

HABERMEHL K. H. 1960:Ueber das Vorkommen dorsaler Corpora sesamoidea an den Zehen einiger Wiederkäuer. Wien. Tierärztl. Mschr. 47:213-224

HAINES R. W. 1942: The tetrapod knee joint. J. Anat. 76: 270-299

HOOD R. C., NEIL W. M. 1948: A modification of alizarin red Stechnique for demonstranting bone formation. Stain Technol. 23: 209-218

KOLDA J. 1936: Srovnávací anatomie zvírat domácích se zřetelem k anatomii člověka. I.část obecná II. nauka o kostech a chrupavkách. Novina, Brno, 914 p.

KONIG H. E. 1992: Anatomie der Katze mit Hinweisen für die tierärztliche Praxis. Gustav Fischer Verlag, Stuttgart - Jena - New York, 222 p.

McCARTHY P. H., WOOD A. K. W. 1987: Anatomical and Radiological Observations of the Sesamoid Bone of the Popliteus Muscle in the Adult Dog and Cat. Anat. Histol. Embryol. 187:58-65

MORITZ A. 1960: Die supra- und parapatellaren Ansatzbildungen beim Hunde. Wien. Tierärztl. Mschr. Festschrift Prof. Schreiber, 47:365-377

NAGLIERI F. 1932: Note anatomiche sul Nutria (Myopotamus Coypus). Apparechio locomotore. Arch. Ital. di

Anat. e di Embryol. 30:470-555

NICKEL R., SCHUMMER A., SEIFERLE E. 1977: Lehrbuch der Anatomie der Haustiere. Band I. Bewegungsapparat. Verlag Paul Parey, Berlin und Hamburg, 539 p.

PEARSON K., DAVIN A. G. 1921: On the sesamoids of the knee joint. Biometrica 13:133-172

PEDERSEN H. E. 1949: The ossicles of the semilunar cartilages of rodents. Anat. Rec. 105:1-7

PFITZNER W. 1892: Beiträge zur Kenntnis des menschlichen Extremitätenskelettes IV. Die Sesambeine des menschlichen Körpers. Schwalbes Morphol. Arbeiten 12:519-762

PREUSS F. 1970: Zur Sesambeinfrage. IX. International Congres of Anatomists, Abstract of papers, Leningrad, 199 p.

PROSÉE. L. 1984: Anatomy of the knee joint of the cat. Acta Anat. 119:40-48

REIGHARD J., JENNINGS H.S. 1930: Anatomy of the Cat. Henry Holt and Comp., New York, 498 p.

RETTERER. E. 1918: Die sesamoidea dorsalia digitorum des Löwen und der Katze. Compt. rend. Soc. biol., 81,:393, ref. Jber. Vet.-Med. 38, 1918:106

ROMMER A. S., PARSONS T. S. 1983: Vergleichende Anatomie der Wirbeltiere. Verlag Paul Parey, Hamburg und Berlin, $624 \mathrm{p}$.

STIEDA L. 1902: Über die Sesambeine des Kniegelenkes. Anat. Anz. 21, Ergänzungsheft:127-130 
Červený Č. and Páral V.: Sesamoid...pp. 79-82.

Plate XXXII.

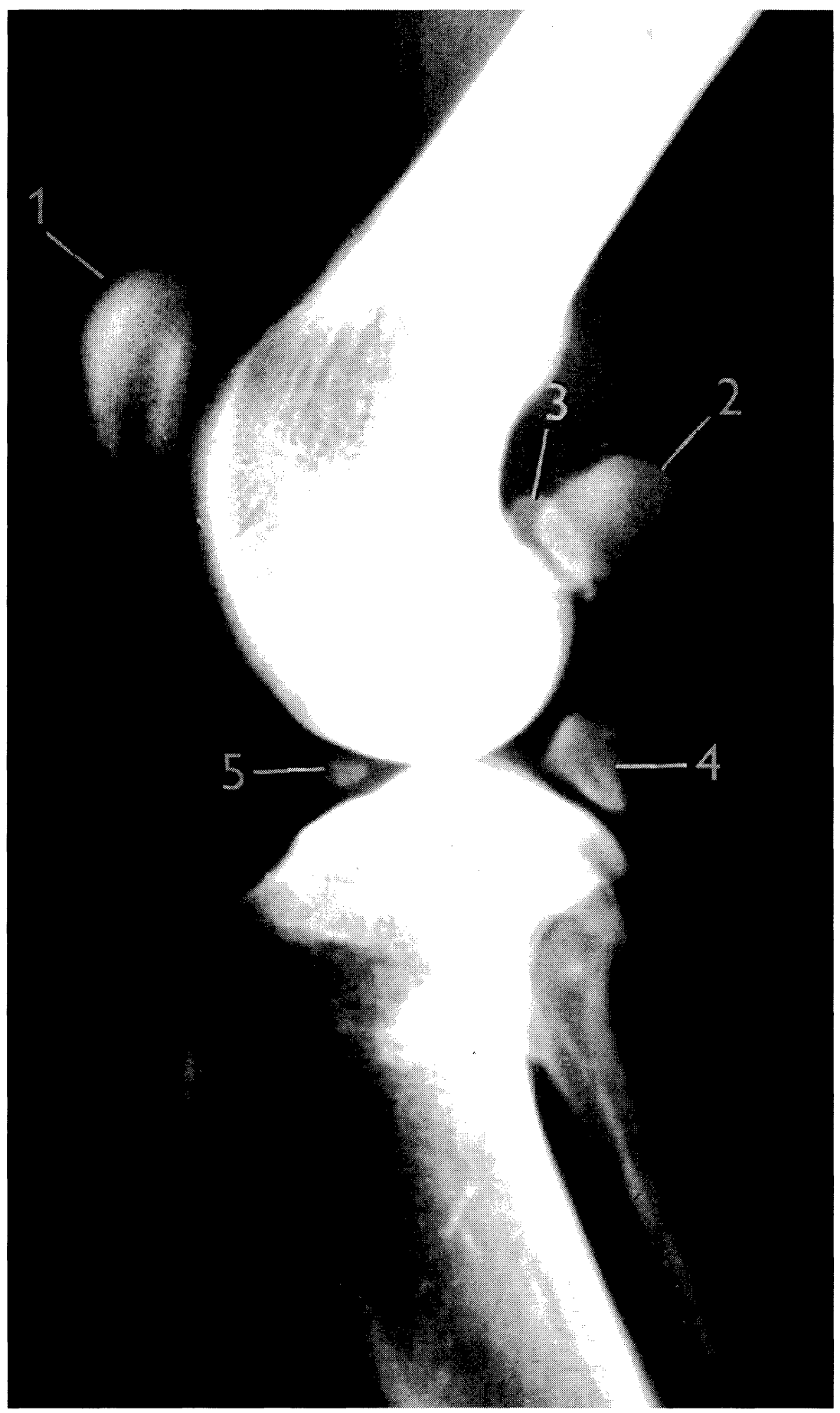

Fig. 1. Radiograph of the knee joint of the puma (Puma concolor) taken in lateromedial projection. 1 - patella, 2 - os sesamoideum $\mathrm{m}$. gastrocnemii laterale, 3 - os sesamoideum m. gastrocnemii mediale, 4 - os sesamoideum $\mathrm{m}$. poplitei, 5 - os menisci medialis. 